\title{
DEVELOPMENT OF METHODICAL COMPETENCE OF A MATH TEACHER AS A PEDAGOGICAL PROBLEM
}

\section{РОЗВИТОК МЕТОДИЧНОЇ КОМПЕТЕНТНОСТІ ВЧИТЕЛЯ МАТЕМАТИКИ ЯК ПЕДАГОГІЧНА ПРОБЛЕМА}

\author{
Liubov MYKHAILENKO, \\ Любов МИХАЙЛЕНКО, \\ Candidate of Pedagogical Sciences, \\ Associate Professor \\ https://orcid.org/0000-0001-5051-5561 \\ mikhailenkolf@gmail.com \\ Vinnytsia Mykhailo Kotsiubynskyi \\ Вінницький державний \\ State Pedagogical University \\ педагогічний університет імені \\ 32 Ostrohsky St., \\ Vinnitsa, Ukraine, 21001 \\ Михайла Коцюбинського \\ $\checkmark$ вулиця Острозького, 32 \\ м. Вінниця, 21100 \\ Original manuscript received: February 01, 2020 \\ Revised manuscript accepted: March 02, 2020
}

\section{ABSTRACT}

The problems of development of methodical competence of mathematics teachers are covered in the article. The analysis, generalization, systematization of theoretical provisions revealed in official documents, scientific and educational-methodical literature are carried out; generalization of own pedagogical experience, as well as analysis of practical experience in the development of methodological competence of the teacher of mathematics. Important for the efficiency of reforming general secondary education is the retraining of working teachers to implement the main directions of the new educational reform. We believe that the effectiveness of reforming school mathematics education is highly dependent on reforming the system of advanced training of mathematics teachers. Not only the content needs to change, but the technologies of professional growth of the next generation of teachers in higher education pedagogical institutions need to be improved and updated. We consider methodical competence one of the main components of the professional competence of a working mathematics teacher. The positive influence of partnership of pedagogical university and school on conditions of methodical development of working mathematics teachers is argued in the article.

It is important to develop a typical educational program for organizing and improving the qualification of pedagogical staff in higher education institutions and to clearly define program learning outcomes - knowledge, skills, ways of thinking, views, values, other personal qualities of mathematics teachers, which can be acquired in the process, identify, plan, evaluate and measure and which the teacher is able to demonstrate after completing the educational program or its individual educational components. The development of teacher education programs is advisable not for specialties but for interdisciplinary programs that are more flexible and tailored to the contemporary needs of school education. The necessity of constant updating of the content of the advanced training courses of mathematics teachers to meet the rapidly changing educational needs of the teacher in the development of methodological competences, at all levels of his professional activity, is noted. 
Key words: professional development of mathematics teacher; advanced training of mathematics teacher; development of methodological competence of the teacher of mathematics.

Актуальність полягає в необхідності підготовки вчителя Нової української школи до реалізації освітньої політики держави шляхом опанування новітніми практиками, технологіями, методиками, формами, методами професійної діяльності на засадах інноваційних освітніх підходів 3 урахуванням потреб педагогів, держави та глобалізованого світу (Наказ МОН України № 36 від 15 січня 2018 року). Успішна професійна діяльність учителя вимагає безперервного навчання в умовах динамічних змін та здатності адаптуватися до них. Прагнення вчителя до розвитку профресійних компетентностей, самовдосконалення й самоосвіти є важливими чинниками його професійного зростання, що забезпечують розширення його можливостей, пізнавальних інтересів та фрормування творчої індивідуальності (Наказ МОН України № 776 від 16 липня 2018 року).

Постановка проблеми. Ключовою умовою розвитку неперервної педагогічної освіти $€$ розвиток сучасних альтернативних моделей професійного та особистісного розвитку. Оскільки підвищення кваліфікації $€$ необхідною умовою атестації педагогічного працівника, то він зобов'язаний постійно підвищувати свій професійний і загальнокультурний рівні та педагогічну майстерність. До основних очікуваних результатів цієї діяльності відносять: підвищення якості підготовки вчителів, освітньої діяльності тощо. Профресійний розвиток учителів математики розглядаємо як центральний впливовий фактор на ефрективність шкільної освіти. Для забезпечення реалізації цих вимог вважаємо за доцільне розглянути особливості розвитку методичної компетентності вчителя математики як складову розвитку його професійної компетенції.

Аналіз попередніх досліджень і публікацій. Вивчення питань профресійного розвитку вчителів математики протягом останнього десятиліття займає центральне місце досліджень як в Україні, так і в багатьох європейських країнах. Автори колективної монографрії "Зарубіжний досвід профресійної підготовки педагогів" описали зарубіжний досвід цього процесу. Крім того, опубліковано 106 статей у "Журналі освіти вчителів математики" 1985 по 2008 рр., у яких описані дослідження, пов'язані з підготовкою вчителів математики. Основні напрями, які розглядаються в цих дослідженнях: ідентичність вчителя, переконання і навички (25\%); практика вчителів (19\%); увага до учнівського мислення (13\%); співробітництво / спільнота вчителів $(11 \%) ;$ навчальний план (8\%); знання математичного змісту (6\%); характеристики професійного розвитку (6\%); характеристики системи (5\%); результати учнів (3\%); та інші напрями (3\%). У статті (Schwarz, 2019), присвяченій професійному розвитку вчителів математики, проведено аналіз різних моделей фооммування методичної компетентності вчителів математики.

На сайті NCTM (Національна рада вчителів математики США та Канади) є окрема сторінка ресурсів професійного розвитку (див. https://www.nctm.org/Conferences-and-Professional-

Development/Professional-Development-Resources/). Публікації в журналах 
NCTM $є$ багатим ресурсом для професійного розвитку, зокрема, використання журнальних статей та книг як вивчення досвіду професійного розвитку. Також пропонуються «Поради для вчителів», добірка тематичних підказок. Академія професійного розвитку NCTM пропонує дво- та п'ятиденні курси по всій території Сполучених Штатів, які $€$ практичними та розроблені для забезпечення розуміння й застосування принципів і стандартів.

В Україні популярні серед учителів освітні платорорми: EdEra - студія онлайн-освіти, що створюе онлайн-курси, інтерактивні підручники, освітні спецпроєкти та моделі інтеграції сучасних освітніх рішень у традиційний освітній процес (https://www.ed-era.com/courses/); Prometheus - проєкт безкоштовної освіти для всіх та зокрема безкоштовні онлайн-курси профресійного розвитку освітян викладачів найкращих університетів світу та досвідчених українських педагогів (https://prometheus.org.ua/courses-for-teachers/).

Різні аспекти професійної підготовки майбутнього вчителя математики у своїх дисертаційних дослідженнях вивчали: І. Акуленко, В. Ачкан, В. Бевз, О. Матяш, Г. Михалін, В. Моторіна, О. Ордановська, С. Раков, О. Семеніхіна, О. Співаковський, Н. Тарасенкова та інші. Серед основних напрямків досліджень можна виділити: вдосконалення процесу формування математичної компетентності учнів (Матяш, 2015; Скворцова, 2010); модель розвитку професійної підготовки вчителів математики (Клокар, 2015; Матяш, 2013; Тарасенкова\&Акуленко, 2011; Головіна, 2019; Prediger, 2019; Sonmark, 2017); використання сучасних технологій у професійному розвитку вчителів математики (Моторіна, 2014; Karsenty, 2018; Hjalmarson, 2017); вимірювання ефективності професійного розвитку вчителів математики (Kaiser, 2019; Zehetmeier, 2017). Мета статті - висвітлення проблеми розвитку методичної компетентності вчителів математики.

Методи та методики дослідження. Аналіз, узагальнення, систематизація теоретичних положень розкритих у офіційних документах, науковій та навчально-методичній літературі; узагальнення власного педагогічного досвіду, а також аналіз практичних напрацювань щодо розвитку методичної компетентності вчителя математики.

Результати та дискусії. Методична компетентність учителя математики $є$ складовою його професійної компетентності. Зважаючи на глосарій педагогічних понять, визначений в останньому законі "Про освіту", вважаємо коректним розглядати поняття "методична компетентність вчителя математики" як динамічну комбінацію його сформованих здатностей розпізнавати й розв'язувати актуальні методичні задачі та аналізувати доцільність й критично оцінювати ефективність використовуваних методичних прийомів у процесі педагогічної діяльності щодо формування математичної компетентності учнів (Михайленко, 2019). Розвиток методичної компетентності вчителя математики розуміємо як набуття нових та вдосконалення раніше набутих здатностей.

Профресійний розвиток педагогічних працівників передбачає постійну самоосвіту, участь у програмах підвищення кваліфікації та будь-які інші 
види i форми профресійного зростання. Безперервний профресійний розвиток може здійснюватися шляхом формальної, неформальної та інформальної освіти. Традиційним видом підвищення кваліфрікації $\epsilon$ навчання в закладах освіти, які мають ліцензію на підвищення кваліфікації або провадять освітню діяльність за акредитованими освітніми програмами. Формами підвищення кваліфрікації є інституційна (очна (денна, вечірня), заочна, дистанційна, мережева), дуальна, на робочому місці, на виробництві тощо. Видами підвищення кваліфікації педагогічних працівників $є$ стажування, участь у сертифрікаційних програмах, тренінгах, семінарах, семінарах-практикумах, семінарах-нарадах, семінарахтренінгах, вебінарах, майстер-класах тощо. Також стажування в кращих педагогічних працівників $€$ одним із видів підвищення кваліфікації, спрямоване на поширення ефективної практики (Накази МОН України №№ 776, 36, 977; Постанова КМУ № 800; закон України “Про освіту”).

Слід звернути увагу, що результати підвищення кваліфікації в суб'єктів підвищення кваліфікації, що мають ліцензію на підвищення кваліфікації або провадять освітню діяльність за акредитованою освітньою програмою (формальна освіта), не потребують окремого визнання чи підтвердження. Проте, результати підвищення кваліфікації в інших суб'єктів підвищення кваліфікації визнаються рішенням педагогічної ради відповідного закладу освіти. Обов'язковою умовою для визнання результатів інших видів підвищення кваліфікації $є$ опис набутих нових та/або вдосконалених відповідно до фаху раніше набутих компетентностей і досягнутих результатів навчання, співвимірних 3 витраченим на це часом (Постанова КМУ № 800).

Отже, на основі викладеного можна зробити висновок про те, що не може бути однієї моделі професійного розвитку вчителів математики, оскільки їх можна умовно поділити на вчителів-початківців, досвідчених вчителів, вчителів-тренерів та осіб, які здобули вищу чи фахову передвищу освіту за іншою спеціальністю та яким не було присвоєно кваліфікації педагогічного працівника. Зміст, методи, фрорми і засоби професійного розвитку кожної виділеної групи вчителів математики мають відрізнятись. Актуальним залишаються питання вимірювання ефективності професійного розвитку та оцінка професійної компетентності педагогів.

Тобто кожен вчитель має бути мотивованим для розвитку власної методичної компетентності та самостійно проєктувати програму професійного особистісного зростання. Зміст ії має містити різні фоорми (інституційна, дуальна) та види підвищення кваліфікації. Згідно "Порядку підвищення кваліфікації педагогічних і науково-педагогічних працівників" для забезпечення підвищення кваліфікації в індивідуальних планах розвитку методичної компетенції мають бути визначені завдання для: вдосконалення раніше набутих та/або набуття нових компетентностей у межах професійної діяльності; набуття досвіду виконання додаткових завдань та обов'язків у межах спеціальності та/або професії та/або займаної посади; формування та розвитку цифрової, управлінської, комунікаційної, медійної, інклюзивної, мовленнєвої компетентностей тощо. 
Учитель має добре знати шкільну математику, розуміти центральні математичні ідеї та вміти правильно донести зміст цих знань до учнів, організувавши різноманітні процеси навчання. Залежно від школи, класу в якому працює вчитель, він сам має визначати, що йому необхідно вивчити саме зараз, тобто створюються умови для побудови особистої траєкторії професійного розвитку вчителя математики. Він має використовувати на своїх уроках ІКТ, упроваджувати новітні технології, щоб максимізувати можливості для співпраці та обговорення, пропонуючи відповідні рівні підтримки учням під час групової роботи і залучаючи до навчання разом у кінці уроку, вміти виконувати роль фрасилітатора. Визначним засобом розвитку методичної компетентності вчителя математики $€$ створення масових відкритих онлайн-курсів та створення і наповнення контенту освітніх порталів та платформ, участь у підготовці відповідних матеріалів. Важливо, щоб отримані вчителем знання та вміння можна було відразу застосувати в процесі навчання учнів. Важливо, щоб підвищення кваліфікації вчителя математики впливало на формування здатності визначати цілі та завдання власного саморозвитку, найближчої та віддаленої перспективи професійної самоосвіти, здатності оцінювати значення своїх соціальних та професійних фрункцій, формувати стійке позитивне ставлення до професійних та суспільних обов'язків.

Зміст курсів підвищення кваліфікації для задоволення освітніх потреб вчителя математики в розвитку методичних компетентностей має бути актуальним для сучасної школи і постійно оновлюватися. Згідно 3 даними, представленими на сайті https://economistua.com/kontseptsiyarozvitku-pedagogichnoyi-osviti-yak-mon-planuye-pidnimati-prestizhnistprofesiyi/, сучасні вчителі виділяють такі бажані напрями підвищення кваліфікації: володіння іноземною мовою - 45\%; профілактика професійного вигорання - 43\%; створення нового освітнього простору 39\%; "наскрізні" навички (навчання протягом життя, вирішення проблем, робота в команді і т. ін.) - 38\%; навички ІКТ для викладання - 33\%; інтеграція дітей з особливими освітніми потребами до процесу навчання - 31\%. У результаті проведеного інтерв'ю 12 вчителів математики Вінниччини можемо стверджувати, що найбільше педагогів цікавлять такі напрями вдосконалення методичних компетентностей: сучасні ІКТ технології на уроках математики, їх можливості та особливості застосування; створення та використання освітніх порталів та платформ; технології розвитку критичного мислення учнів на уроках математики; реалізація проєктного навчання на уроках математики.

Педагогічні дослідження свідчать про те, що розвиток методичної компетентності вчителів математики $€$ ефективним, за умови: підвищення рівня математичних та методичних знань учителів; безпосереднього застосування їx; розвиток умінь; здатність помічати, аналізувати і реагувати на мислення учнів; здатність розуміти іншу людину, чути, взаємодіяти, комунікувати; вдосконалення критичного мислення i аналітичних здібностей вчителів, створення продуктивних звичок розумової діяльності; розвитку креативності, здатності впроваджувати 
сучасні методи, фрорми навчання учнів математики; створення колегіальних відносин та структури, які підтримують продовження навчання. Крім того, для розвитку методичної компетентності вчителів математики необхідними є: мотивація до творчої педагогічної діяльності та формування психологічної готовності вчителів до професійного саморозвитку; значні часові інвестиції для професійного зростання; створення комфортних та ефективних умов для активного самовдосконалення та постійного професійного розвитку; систематична підтримка з боку керівництва школи; можливість отримання фрінансової допомоги у формі грантів, премій, нагород.

Висновки. Здійснивши аналіз описаного досвіду професійної підготовки педагогів, вважаємо, що розвитку методичної компетентності вчителів математики сприятиме:

- створення умов для здатності спроєктувати і провести на належному рівні урок математики; виявляти помилки та недоліки в математичних знаннях та уміннях, в логіці міркувань, пояснювати різницю між фрактами і наслідками, рекомендувати методи обґрунтування тверджень; планувати та організовувати процес навчання учнів математики, досліджувати результативність навчання, робити висновки про ефрективність використовуваних методів, прийомів та засобів навчання та виховання; формувати в учнів та студентів розуміння основ математичного моделювання, готовність до застосування моделювання для розв'язування задач; аналізувати, проєктувати, впроваджувати та вдосконалювати навчальнометодичне оснащення навчання математики в старшій школі (Освітньопрофесійна програма “Середня освіта (математика, інформатика)");

- розробка освітніх програм підвищення кваліфікації вчителів не тільки за спеціальностями, а й за міждисциплінарними програмами, що $є$ більш гнучкими та налаштованими на сучасні потреби шкільної освіти. Важливо розробити типову освітню програму організації й проведення підвищення кваліфікації педагогічних працівників закладами вищої педагогічної освіти та чітко визначити програмні результати навчання знання, уміння, навички, способи мислення, погляди, цінності, інші особисті якості учителів математики, набуті в процесі фахової підготовки, які можна ідентифікувати, спланувати, оцінити і виміряти та які вчитель здатен продемонструвати після завершення освітньої програми або окремих її освітніх компонентів;

- постійне оновлення змісту курсів підвищення кваліфікації для задоволення швидкозмінних освітніх потреб вчителя в розвитку професійних та зокрема методичних компетентностей на всіх рівнях його професійної діяльності;

- використання різноманітних організаційних фрорм і методів професійної підготовки вчителя, орієнтування на компетентнісний, особистісно-орієнтований, діяльнісний підхід через інтерактивні форми і методи навчання, проблемні, проєктно-дослідницькі методики на основі комплексного методичного й інформаційного забезпечення освітнього процесу; 
- створення умов для розробки індивідуальних траєкторій профресійного розвитку;

- впровадження нових організаційних форм підвищення кваліфрікації вчителів у контексті партнерства школи та закладу вищої освіти;

- координація співпраці між закладами вищої педагогічної освіти та загальної середньої освіти щодо розвитку професійної компетентності вчителя математики;

- підвищення кваліфрікації досвідчених вчителів під час залучення їх до організації і проведення педагогічної практики студентів;

- розкриття вимог до змісту, фрорми електронного портфоліо вчителя математики;

- створення чіткої технологічної карти проходження педагогічної інтернатури з метою професійної адаптації новопризначених учителів;

- створення чіткої технологічної карти щодо отримання профресійної кваліфікації педагогічного працівника особами, які здобули вищу чи фрахову передвищу освіту за іншою спеціальністю;

- відбір та організація підготовки супервізорів, які відповідають за процес адаптації новопризначених учителів до умов профресійної діяльності в закладі освіти;

- відбір та організація підготовки тренерів (менторів, тьюторів, фасилітаторів) для підвищення кваліфікації різних категорій учителів;

- посилення кооперативної, проблемної, дослідної спрямованості в розвитку методичної компетентності; заміна традиційної ролі викладача на роль наставника.

\section{Література}

1.Goldsmith, L.T., Doerr, H.M. \& Lewis, C.C. J Math Teacher Educ (2014) 17: 5. https://doi.org/10.1007/s10857-013-9245-4

2. Hjalmarson, M.A. J Math Teacher Educ (2017) 20: 281. https://doi.org/10.1007/s10857-015-9323-x

3.Kaiser, G. \& König, J. High Educ Policy (2019). https://doi.org/10.1057/s41307-019-00139-z

4. Karsenty R. (2018) Professional Development of Mathematics Teachers: Through the Lens of the Camera. In: Kaiser G., Forgasz H., Graven M., Kuzniak A., Simmt E., Xu B. (eds) Invited Lectures from the 13th International Congress on Mathematical Education. ICME-13 Monographs. Springer, Cham

5.Prediger, S., Roesken-Winter, B. \& Leuders, T. J Math Teacher Educ (2019) 22: 407. https://doi.org/10.1007/s10857-019-09434-3

6. Schwarz B., Kaiser G. (2019) The Professional Development of Mathematics Teachers. In: Kaiser G., Presmeg N. (eds) Compendium for Early Career Researchers in Mathematics Education. ICME-13 Monographs. Springer, Cham

7. Sonmark, K. et al. (2017), 'Understanding teachers' pedagogical knowledge: report on an international pilot study", OECD Education Working Papers, No. 159, OECD Publishing, Paris. http://dx.doi.org/10.1787/43332ebd-en

8. Stefan Zehetmeier. Researching the sustainable impact of professional development programmes. CERME 10 , Feb 2017, Dublin, Ireland. 〈hal-01949017)

9.Головіна О.В. Професійний розвиток вчителів: як це відбувається у Фінляндії. [Електронний ресурс] / О.В. Головіна. - Сайт «Нова українська школа». - Режим доступу: https://nus.org.ua/articles/profesijnyj-rozvytok-vchyteliv-yak-tse- 
vidbuvayetsya-u-finlyandiyi/

10. Закон України «Про освіту» [Електронний ресурс]. - Режим доступу: https://zakon.rada.gov.ua/laws/show/2145-19

11. Зарубіжний досвід професійної підготовки педагогів: аналітичні матеріали / [Авшенюк Н.М., Дяченко Л.М., Котун К.В., Марусинець М.М., Огієнко O.І., Сулима О.В., Постригач Н.О.]. - Київ : ДКС «Центр», 2017. - 83 с.

12. Клокар Н.І. Регіональна модель управління системою підвищення кваліфікації педагогічних кадрів / Н.І. Клокар // Народна освіта, 2015. - Випуск №1(25), [Електронний ресурс]. - Режим доступу: phttps://www.narodnaosvita.kiev.ua/?page_id=3278 (Дата звернення 25.08.2019)

13. Матяш О.І. Удосконалення професійної підготовки вчителя математики в умовах компетентнісного підходу./ О.І. Матяш // Международный научный журнал Acta Universitatis Pontica Euxinus.- Специальный выпуск. - Варна, 2015. C. 241-246.

14. Матяш О.І. Формування методичної компетентності 3 навчання геометрії майбутніх учителів математики: автореф. дис. ... д-ра пед. наук: 13.00.02/ Національний педагогічний університет імені Н.П. Драгоманова. Київ, 2014. 42с.

15. Михайленко Л.Ф. Методична компетентність вчителя математики як педагогічна проблема / Л.Ф. Михайленко, А.Л. Воєвода // Фізико-математична освіта, 2019. - Випуск 1(19). - С. 135-141. DOI 10.31110/2413-1571-2019-019-1-021

16. Моторіна В.Г. Профресійна компетентність вчителя математики профільної школи: Навчальний посібник для студентів природничо-математичних спеціальностей педагогічних ВНЗ/ Валентина Григорівна Моторіна. - Харків: ХНПУ, 2014. - 267c.

17. Освітньо-професійна програма “Середня освіта (математика, інформатика)” другого (магістерського) рівня вищої освіти за спеціальністю 014 Середня освіта (Математика), галузі знань 01 Освіта/Педагогіка. - Сайт ВДПУ імені Михайла Коцюбинського - [Електронний ресурс]. - Режим доступу: http://www.vspu.edu.ua/content/img/education/task.pdf

18. Порядок підвищення кваліфікації педагогічних і науково-педагогічних працівників: Постанова Кабінету Міністрів України від 21 серпня 2019 р. № 800 . [Електронний ресурс]. - Режим доступу: https://www.kmu.gov.ua/ua/npas/deyakipitannya-pidvishchennya-kvalifikaciyi-pedagogichnih-i-naukovo-pedagogichnih-t210819

19. Про затвердження Концепції розвитку педагогічної освіти: Наказ Міністерства освіти і науки України № 776 від 16 липня 2018 року. - [Електронний ресурс]. - Режим доступу: https://mon.gov.ua/ua/npa/pro-zatverdzhennya-koncepciyirozvitku-pedagogichnoyi-osviti

20. Про затвердження Положення про акредитацію освітніх програм, за якими здійснюється підготовка здобувачів вищої освіти: Наказ Міністерства освіти і науки України № 977 від 11 липня 2019 року. - [Електронний ресурс]. - Режим доступу: http://search.ligazakon.ua/l_doc2.nsf/link1/RE33851.html

21. Про затвердження Типової освітньої програми організації і проведення підвищення кваліфікації педагогічних працівників закладами післядипломної педагогічної освіти: Наказ Міністерства освіти і науки України № 36 від 15 січня 2018 року - [Електронний ресурс]. - Режим доступу: https://mon.gov.ua/ua/npa/prozatverdzhennya-tipovoyi-osvitnoyi-programi-organizaciyi-i-provedennya-pidvishennyakvalifikaciyi -pedagogichnih-pracivnikiv-zakladami-pislyadiplomnoyi-pedagogichnoyi-osviti

22. Скворцова С.О. Формування професійної компетентності майбутнього вчителя математики / С.О. Скворцова. - Педагогічна наука: історія, теорія, практика, тенденції розвитку, 2010. - Вип.4. - [Електронний ресурс]. - Режим доступу: http://intellect-invest.org.ua /pedagog_editions_emagazine_ pedagogical_science_vypuski_n4_2010_st_4/ (Дата звернення 25.08.2019) 
23. Тарасенкова Н.А. Методичні компетентності у системі фахової підготовки майбутнього вчителя математики / Н.А. Тарасенкова, І.А. Акуленко // Вища освіта України, 2011. - № 3.- С. 53-66. - [Електронний ресурс]. - Режим доступу: http://nbuv.gov.ua/UJRN/vou 2011311 (Дата звернення 25.08.2019)

\section{References}

1. Goldsmith, L.T., Doerr, H.M. \& Lewis, C.C. J Math Teacher Educ (2014) 17: 5. https://doi.org/10.1007/s10857-013-9245-4.

2. Hjalmarson, M.A. J Math Teacher Educ (2017) 20: 281. https://doi.org/10.1007/s10857-015-9323-x.

3. Kaiser, G. \& König, J. High Educ Policy (2019). https://doi.org/10.1057/s41307-019-00139-z.

4. Karsenty R. (2018) Professional Development of Mathematics Teachers: Through the Lens of the Camera. In: Kaiser G., Forgasz H., Graven M., Kuzniak A., Simmt E., Xu B. (eds) Invited Lectures from the 13th International Congress on Mathematical Education. ICME-13 Monographs. Springer, Cham.

5. Prediger, S., Roesken-Winter, B. \& Leuders, T. J Math Teacher Educ (2019) 22: 407. https://doi.org/10.1007/s10857-019-09434-3.

6. Schwarz B., Kaiser G. (2019) The Professional Development of Mathematics Teachers. In: Kaiser G., Presmeg N. (eds) Compendium for Early Career Researchers in Mathematics Education. ICME-13 Monographs. Springer, Cham.

7. Sonmark, K. et al. (2017), 'Understanding teachers' pedagogical knowledge: report on an international pilot study", OECD Education Working Papers, No. 159, OECD Publishing, Paris. http://dx.doi.org/10.1787/43332ebd-en.

8. Stefan Zehetmeier. Researching the sustainable impact of professional development programmes. CERME 10 , Feb 2017, Dublin, Ireland. 〈hal-01949017).

9. Holovina O.V. (2019) Profesiinyi rozvytok vchyteliv: yak tse vidbuvaietsia u Finliandii. [Professional development of teachers: how it is in Finland ]. Sait "Nova ukrainska shkola» - Website New Ukrainian School. Retrieved from https://nus.org.ua/articles/profesijnyj-rozvytok-vchyteliv-yak-tse-vidbuvayetsya-ufinlyandiyi/ [in Ukrainian].

10. Zakon Ukrainy «Pro osvitu» [Law of Ukraine "About Education"]. (n.d.). zakon.rada.gov.ua. Retrieved from https://zakon.rada.gov.ua/laws/show/2145-19 [in Ukrainian].

11. Avsheniuk N.M. et al (2017). Zarubizhnyi dosvid profesiinoi pidhotovky pedahohiv: analitychni materialy [Foreign experience of teacher training: analytical materials] Kyiv : DKS «Tsentr» [in Ukrainian].

12. Klokar N.I. (2015) Rehionalna model upravlinnia systemoiu pidvyshchennia kvalifikatsii pedahohichnykh kadriv [Regional model of management of advanced training of pedagogical personnel]. Narodna osvita - Public education. 1(25). Retrieved from phttps://www.narodnaosvita.kiev.ua/?page_id=3278 [in Ukrainian].

13. Matiash, O.I. (2015). Udoskonalennia profesiinoi pidhotovky vchytelia matematyky $v$ umovakh kompetentnisnoho pidkhodu [Improvement of professional training of mathematics teacher in conditions of competent approach]. Mezhdunarodnbi nauchnыi zhurnal Acta Universitatis Pontica Euxinus - International scientific journal Acta Universitatis Pontica Euxinus, 241-246 [in Bulgaria].

14. Matiash, O.I. (2014) Formuvannia metodychnoi kompetentnosti z navchannia heometrii maibutnikh uchyteliv matematyky [Formation of methodical competence in teaching the geometry of future mathematics teachers]. Extended abstract of Doctor's thesis. Kyiv: Natsionalnyi pedahohichnyi universytet imeni N.P. Drahomanova [in Ukrainian].

15. Mykhailenko L.F., Voievoda A.L. (2019). Metodychna kompetentnist 
vchytelia matematyky yak pedahohichna problema [Methodical competence of teacher mathematics as a pedagogical problem]. Fizykomatematychna osvita - Physical and mathematical education. Issue 1(19). 135-141. DOI: 10.31110/2413-1571-2019-019-1021 [in Ukrainian].

16. Motorina, V.H. (2014) Profesiina kompetentnist vchytelia matematyky profilnoi shkoly: Navchalnyi posibnyk dlia studentiv pryrodnycho-matematychnykh spetsialnostei pedahohichnykh VNZ - Professional competence of the teacher of the mathematics of the profile school. Kharkiv: KhNPU [in Ukrainian].

17. Osvitno-profesiina prohrama "Serednia osvita (matematyka, informatyka)" druhoho (mahisterskoho) rivnia vyshchoi osvity za spetsialnistiu 014 Serednia osvita (Matematyka), haluzi znan 01 Osvita/Pedahohika. [Educational-professional program "Secondary education (mathematics, computer science)" of the second (master's) level of higher education, specialty 014 Secondary education (Mathematics), branches of knowledge 01 Education / Pedagogy] (n.d.). vspu.edu.ua. Retrieved from http://www.vspu.edu.ua/content/img/education/task.pdf [in Ukrainian].

18. Poriadok pidvyshchennia kvalifikatsii pedahohichnykh i naukovopedahohichnykh pratsivnykiv: Postanova Kabinetu Ministriv Ukrainy vid 21 serpnia 2019 r. № 800. [Procedure of professional development of pedagogical and scientificpedagogical staff: Resolution of the Cabinet of Ministers of Ukraine of August 21, 2019 No. 800.]. kmu.gov.ua. Retrieved from https://www.kmu.gov.ua/ua/npas/deyakipitannya-pidvishchennya-kvalifikaciyi-pedagogichnih-i-naukovo-pedagogichnih-t210819 [in Ukrainian].

19. Pro zatverdzhennia Kontseptsii rozvytku pedahohichnoi osvity: Nakaz Ministerstva osvity i nauky Ukrainy № 776 vid 16 lypnia 2018 roku. [On approval of the Concept of development of teacher education: Order of the Ministry of Education and Science of Ukraine No. 776 of July 16, 2018]. mon.gov.ua. Retrieved from https://mon.gov.ua/ua/npa/pro-zatverdzhennya-koncepciyi-rozvitku-pedagogichnoyiosviti [in Ukrainian].

20. Pro zatverdzhennia Kontseptsii rozvytku pedahohichnoi osvity: Nakaz Ministerstva osvity i nauky Ukrainy № 776 vid 16 lypnia 2018 roku. [On approval of the Regulations on accreditation of educational programs under which higher education applicants are trained: Order of the Ministry of Education and Science of Ukraine No. 977 of July 11, 2019.]. search.ligazakon.ua. Retrieved from http://search.ligazakon.ua/l doc2.nsf/link1/RE33851.html [in Ukrainian].

21. Pro zatverdzhennia Typovoi osvitnoi prohramy orhanizatsii i provedennia pidvyshchennia kvalifikatsii pedahohichnykh pratsivnykiv zakladamy pisliadyplomnoi pedahohichnoi osvity: Nakaz Ministerstva osvity i nauky Ukrainy № 36 vid 15 sichnia 2018 roku [On Approval of the Model Educational Program for the Organization and Conducting of Advanced Training of Pedagogical Staff in Postgraduate Teacher Education Institutions: Order of the Ministry of Education and Science of Ukraine No. 36 of January 15, 2018]. mon.gov.ua. Retrieved from https://mon.gov.ua/ua/npa/prozatverdzhennya-tipovoyi-osvitnoyi-programi-organizaciyi-i-provedennya-pidvishennyakvalifikaciyi-pedagogichnih-pracivnikiv-zakladami-pislyadiplomnoyi-pedagogichnoyiosviti [in Ukrainian].

22. Skvortsova, S.O. (2010). Formuvannia profesiinoi kompetentnosti maibutnoho vchytelia matematyky [Formation of professional competence of the future teacher of mathematics]. Pedahohichna nauka: istoriia, teoriia, praktyka, tendentsii rozvytku - Pedagogical science: history, theory, practice, trends of development, 4. Retrieved from http://intellect-invest.org.ua /pedagog_editions_emagazine_pedagogical_science_vypuski_n4_2010_st_4/ [in Ukrainian].

23. Tarasenkova N.A. \& Akulenko I.A. (2011). Metodychni kompetentnosti u 
systemi fakhovoi pidhotovky maibutnoho vchytelia matematyky [Methodical competencies in the system of professional training of the future teacher of mathematics.]. Vyshcha osvita Ukrainy - Higher education of Ukraine. Retrieved from http://nbuv.gov.ua/UJRN/vou_2011_3_11 [in Ukrainian].

\section{АНОТАЦІЯ}

У статті висвітлено проблеми розвитку методичної компетентності вчителів математики. Проведено аналіз, систематизацію теоретичних положень, розкритих в офріційних документах, науковій та навчальнометодичній літературі; узагальнення власного педагогічного досвіду, а також практики щодо розвитку методичної компетентності вчителя математики. Важливою для ефрективності реформування загальної середньої освіти $\epsilon$ перепідготовка вчителів до реалізації основних напрямів нової освітньої рефоорми. Вважаємо, що ефективність перебудови икільної математичної освіти значно залежить від реформування системи підвищення кваліфрікації вчителя математики. Має змінитися не тільки зміст, а й технології професійного зростання вчителя нового покоління в педагогічних закладах вищої освіти.

Методичну компетентність вважаємо однією з основних складових профресійної компетентності вчителя математики. У статті аргументовано позитивний вплив партнерської взаємодії педагогічного університету та школи на умови методичного розвитку вчителів математики. Важливо розробити типову освітню програму організації і проведення підвищення кваліфрікації педагогічних працівників закладами вищої педагогічної освіти та чітко визначити програмні результати навчання - знання, уміння, навички, способи мислення, погляди, цінності, інші особисті якості учителів математики, набуті в процесі фрахової підготовки, які можна ідентифрікувати, спланувати, оцінити і виміряти та які вчитель здатен продемонструвати після завершення освітньої програми або окремих ї освітніх компонентів. Розробка освітніх програм підвищення кваліфрікації вчителів доцільна не тільки за спеціальностями, а за міждисциплінарними програмами, що є більш гнучкими та налаштованими на сучасні потреби шкільної освіти. Зазначено необхідність постійного оновлення змісту курсів підвищення кваліфікації вчителів математики для задоволення швидкозмінних освітніх потреб в розвитку методичних компетентностей на всіх рівнях його професійної діяльності.

Ключові слова: профресійний розвиток вчителя математики; підвищення кваліфікації вчителя математики; розвиток методичної компетентності вчителя математики. 